\title{
Use of biogas plants on a national and international scale
}

\author{
Barbora BENCOOVA*1, Roland GROSOS ${ }^{2}$, Marian GOMORY ${ }^{3}$, Kamila BACOVA 4 \\ and Silvia MICHALKOVA
}

\begin{abstract}
Authors' affiliations and addresses:
${ }^{1}$ Faculty of Mining, Ecology, Process Control and Geotechnologies Technical University of Kosice, PK 19, 04200 Košice, Slovak Republic e-mail: barbora.bencoova@tuke.sk

${ }^{2}$ Faculty of Mining, Ecology, Process Control and Geotechnologies Technical University of Kosice, PK 19, 04200 Košice, Slovak Republic e-mail: roland.grosos@tuke.sk
\end{abstract}

${ }^{3}$ Faculty of Mining, Ecology, Process Control and Geotechnologies Technical University of Kosice, PK 19, 04200 Košice, Slovak Republic e-mail: marian.gomory@tuke.sk

${ }^{4}$ Faculty of Mining, Ecology, Process Control and Geotechnologies Technical University of Kosice, PK 19, 04200 Košice, Slovak Republic e-mail: kamila.bacova@tuke.sk

${ }^{5}$ Faculty of Mining, Ecology, Process Control and Geotechnologies Technical University of Kosice, PK 19, 04200 Košice, Slovak Republic e-mail: silvia.michalkova@tuke.sk

\section{*Correspondence:}

Barbora Bencoova, Faculty of Mining, Ecology, Process Control and Geotechnologies Technical University of Kosice, PK 19, 04200 Košice, Slovak Republic

tel.: +42155602 2929

e-mail: barbora.bencoova@tuke.sk

How to cite this article:

Bencoova, B., Grosos R., Gomory, M., Bacova, K. (2021). Use of biogas plants on a national and international scale. Acta Montanistica Slovaca. Volume 26 (1) 139-148

DOI:

https://doi.org/10.46544/AMS.v26i1.12

\begin{abstract}
Renewable energy can be used from several natural sources, which are capable of wind, sun, water, geothermal springs, or biomass. Energy from these sources is clean, safe and inexhaustible. The use of alternative sources is becoming part of all realistic scenarios and promotes sustainable development and energy security in Europe as well. Renewable energy sources form a relatively significant part of primary energy sources in many countries. Thanks to the undeniable advantages of their use, they form another higher share of combined energy production in Slovakia. In addition, the correct location of renewable energy sources can be a key element in the development of individual regions, which can contribute to achieving better social and economic cohesion in the country. Given these obvious environmental and economic benefits, efficient use of renewable energy sources is receiving increasing attention and support from responsible officials and the general public around the world, including Slovakia. The main goal of this paper was to evaluate the use of renewable resources in Slovakia with a focus on biogas plants. We also evaluate the position of Slovakia within the EU in this area and find out what is the current situation of biogas plants in Slovakia.
\end{abstract}

\section{Keywords}

Renewable energy sources, biogas plants, energy transformation, 


\section{Introduction}

Renewable energy allows us to diversify our energy supply (Stürmer et al., 2011). The potential for renewable energy resources is enormous because they can, in principle, exponentially exceed the world's energy demand; therefore, these types of resources will have a significant share in the future global energy portfolio, much of which is now concentrating on advancing their pool of renewable energy resources (Ellabban et al., 2014). This increases our security of supply and improves Europe's competitiveness, creating new sectors, jobs, economic growth and export opportunities while reducing greenhouse gas emissions (Ciucci, 2020). Strong growth in renewable energy by 2030 could create more than 3 million jobs, including small and medium-sized enterprises. If Europe maintains its leading position in the field of renewable energy, our global competitiveness will also increase as the 'clean technologies' sector grows in the world (Kleinert, Schmidt, 2019). However, the economic crisis has made investors in the energy sector more cautious (Pozo, Sauma and Contreras, 2013). The farming sector, in general, is a large producer of manure (Jaber et al., 2004; Svensson et al., 2006; Uddin et al., 2010) and thereby also a large producer of greenhouse gases (Fan et al., 2007; Bauer et al., 2010).

In European liberalised energy markets, the growth of renewable energy depends on private sector investment, which in turn depends on the stability of renewable energy policy. Investments in infrastructure, production and logistics also require related investments - in test facilities, cable production, factories and ships for the construction of offshore wind energy installations (Sauma and Oren, 2009). It set priorities and goals for the energy sector until year 2035 with a view to 2050. The main goal of the European Parliament of the Slovak Republic is to ensure a reliable, safe and efficient supply of all forms of energy at affordable prices, taking into account consumer protection and sustainable development. The Slovak Republic places great emphasis on air quality, reduction of greenhouse gas emissions, climate change mitigation, security of supply of all types of energy and their affordability. In 2019, the Slovak Republic committed itself to a commitment to achieve carbon neutrality by 2050. The SR has balanced the share of nuclear fuel and fossil fuels in gross domestic consumption. The development of energy in the Slovak Republic is aimed at optimising the energy mix so that greenhouse gas emissions are reduced as much as possible and pollutants while maintaining, resp. increasing energy security and affordability of different types of energy (INEKP,2019).

An indicator of the share of renewable energy in gross final energy consumption is shown in Fig. 1. This indicator is based on the definitions included in Directive 2009/28 / EC (Renewable Energy Directive) on the promotion of the use of energy from renewable sources. It is calculated on the basis of data collected under Regulation (EC) No 1099/2008 on energy statistics (NECP, 2019). This indicator measures the extent to which the use of renewable energy is widespread and the extent to which renewable fuels have replaced fossil and/or nuclear fuels, thus contributing to the decarbonisation of the EU economy. Renewable energy plays a key role in the Commission's long-term strategy. EU legislation on the promotion of renewable energy sources has evolved considerably in recent years (COM, 2011).

The indicator of the share of renewable energy in final energy consumption from 2004 to 2019 ranges from $0.1 \%$ to $56.3 \%$. The highest increase in this indicator was recorded in countries such as Denmark (from $14.8 \%$ to $37.2 \%$ ), Sweden (from $38.7 \%$ to $56.4 \%$ ), Finland (from $29.2 \%$ to $43.1 \%$ ). \%) and Greece (from $7.1 \%$ to $19.7 \%$ ). The lowest increases can be seen in Slovenia (from 18.4\% to 22\%), Croatia (from 23.4\% to 28.5\%) and Poland (from $6.9 \%$ to $12.1 \%$ ). Currently, the leading country is Sweden, whose share of renewable energy in final energy consumption exceeds $56 \%$. Luxembourg is the country that uses renewable energy the least. Slovakia shows an increase of $10.5 \%$ from 2004 to 2019 (from 6.4\% to 16.9\%). According to statistics, we can say that only 14 countries have succeeded in meeting the targets set for 2020.

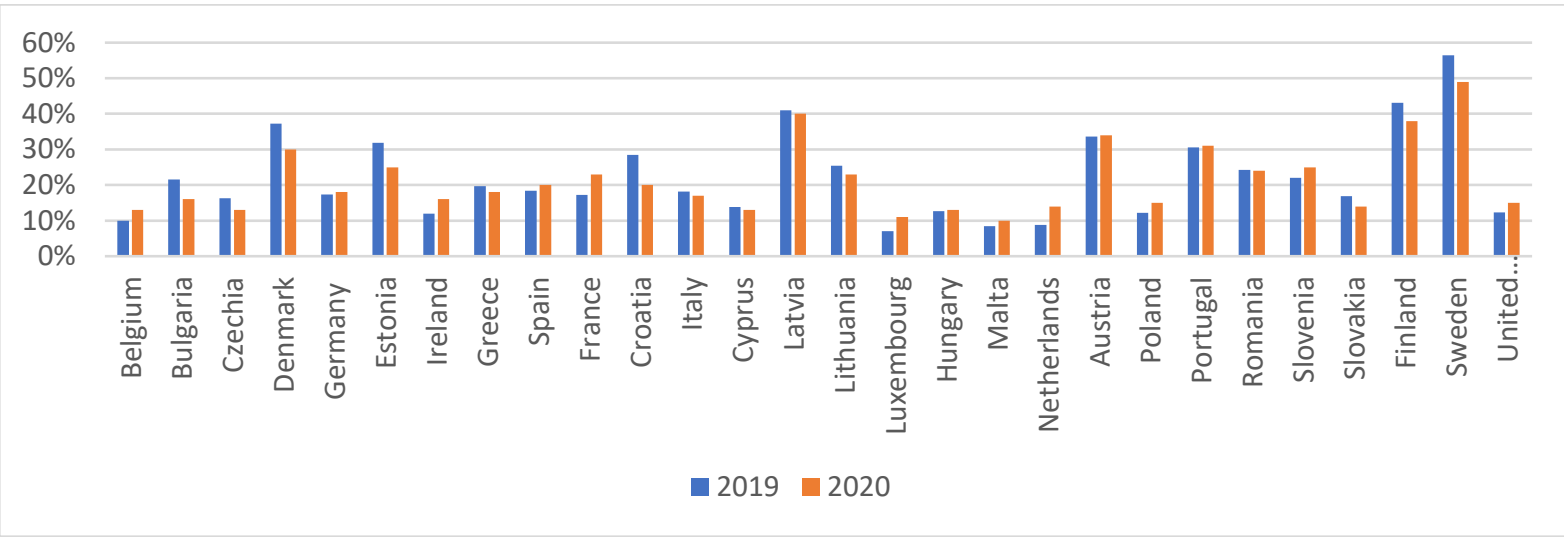

Fig. 1. Share of renewable energy in gross energy consumption in EU - 28 in 2019 and 2020.

Source: Eurostat Database 
In 2009, EU leaders set a target of a $20 \%$ share of renewable energy in EU energy consumption by 2020. In 2018 , it was agreed to achieve a $20 \%$ share of energy from renewable sources in energy consumption in the EU by 2030 (Detersová, K., 2020).

\section{The Current state of Renewable energy in Slovakia}

From 2004 to 2015, the Slovak Republic experienced an upward trend in energy from renewable sources (from $6.4 \%$ to 13\%). Between 2016 and 2018, it recorded a slight decrease of 1\% on average. In contrast, in 2019, it recorded an increase to $16.9 \%$, while the target for 2020 was $14 \%$ (Fig. 2).

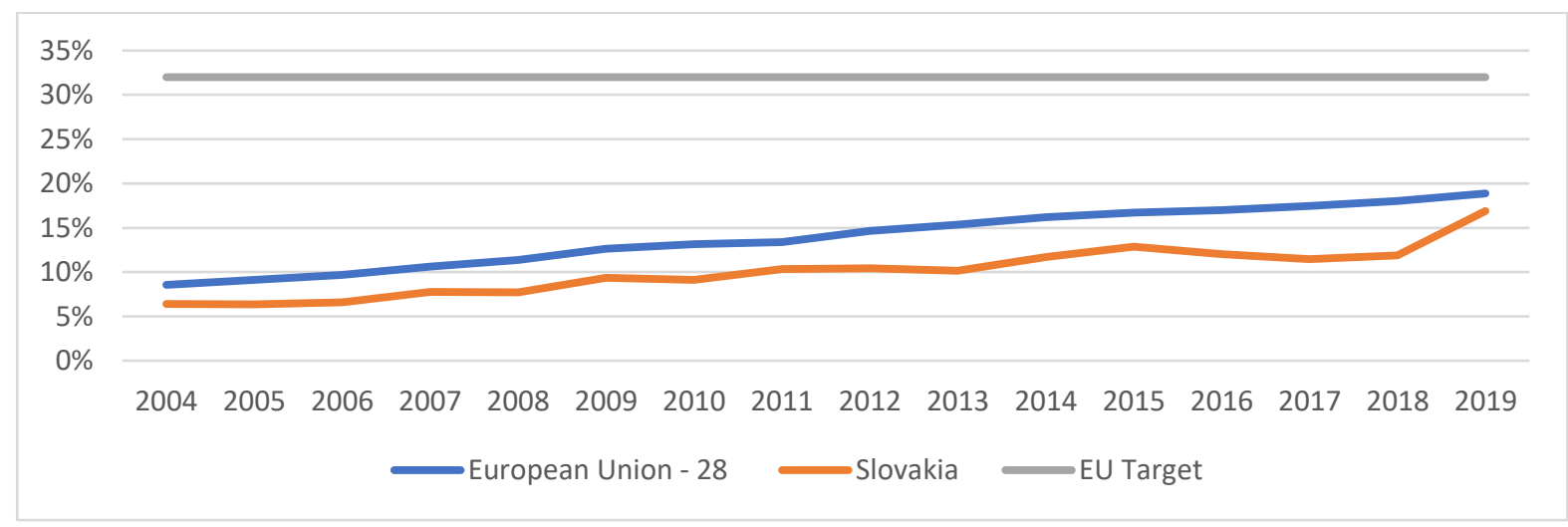

Fig. 2. Share of renewables in gross final energy consumption in Slovakia, 2004 -2019 Source: Eurostat Database

The European Union is setting a binding target for the share of energy from renewable sources in final gross energy consumption, which should be $32 \%$ by 2030 . The Slovak Republic proposes a target of $19.2 \%$ by 2030 , which is an increase of 5.2\% compared to the set target valid until 2020. Additional costs in the field of renewable energy sources and estimated at 4.3 billion euros. Based on the estimated increase in installed capacity for electricity and heat from renewable energy sources, respectively, these investment costs include the electricity and heat sectors (INEKP, 2019).

EU Directive 2018/2001 has set an overall EU target for renewable energy for 2030 since 2021 as part of the new Clean Energy for All Europeans package. The primary emphasis should be on energy efficiency. Increasing energy efficiency is a priority in all carbon offset scenarios. All carbon offset scenarios proposed in the plan envisage at least a 30 per cent share of energy from renewable sources by 2030. Higher energy efficiency is key in new and existing buildings. Buildings, including homes, could produce more energy than they use. Consumers will receive more controlled and predictable energy bills, and, for example, household automation should have a greater impact on energy consumption. Significant efficiency can be achieved through energy efficiency measures such as recycling, efficient production processes and product life extension.

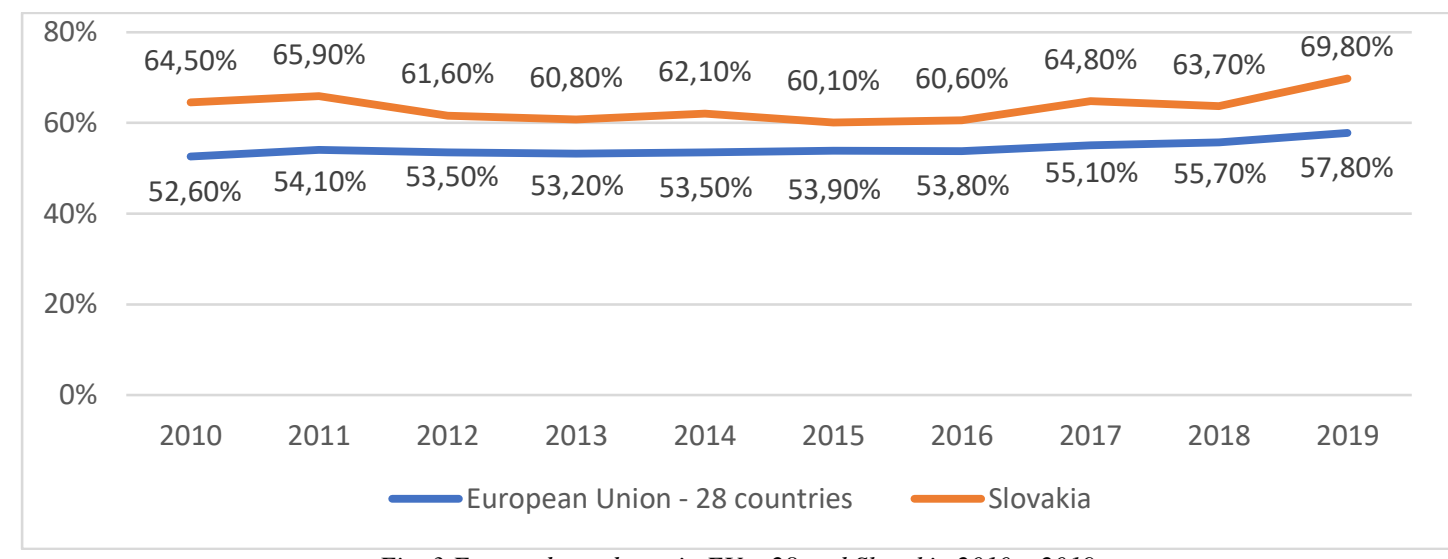

Fig. 3 Energy dependency in EU - 28 and Slovakia 2010 - 2019

Source: Eurostat Database

The dependency rate shows the actual extent to which a specific region's or country's economy (in this case the whole EU) relies upon imports in order to meet its energy needs. It is measured by the share of net imports (imports 
- exports) in gross inland energy consumption (meaning the sum of energy produced and net imports). The dependency ratio was equal to 58\% recorded by the EU in 2019, which means that more than two EU energy needs are met by net imports. In Maltes, Luxembourg and Cyprus, the dependency rate is more than $90 \%$. In Romania, Denmark and Estonia, this dependency rate is $25 \%$. In Slovakia, the rate of dependence on energy imports was $56 \%$ in 2000, while in 2019 this rate rose to $70 \%$.

Approximately $80 \%$ of energy imports are petroleum products in Cyprus, Malta, Greece, Sweden and Romania and more than a third is gas in Hungary, Austria and Italy. Around $20 \%$ of energy imports are solid fuels in Slovakia and Poland, which shows suggests the big difference between various EU countries.

\section{Renewable energy support schemes}

The Slovak Republic, as an EU Member State, has a responsibility to ensure effective management and control systems for its operational programs, as well as tasks to ensure a strategic approach, the ability to address synergies and complementarities to address specific challenges at sub-regional and local levels. Each EU Member State is obliged to apply the Union's policies at the national and regional level, with an impact on social, economic and territorial cohesion, in accordance with the principles of subsidiarity. The Partnership Agreement should be a strategic document in accordance with the draft general EU regulation; therefore, the Slovak Partnership Agreement and programs of the Slovak Republic for 2021 - 2027 will be prepared in accordance with strategic and conceptual documents at the national level relating to individual areas of support from EU funds. Especially with the Vision and Development Strategy of the Slovak Republic until 2030.

\section{Five areas of the Slovak republic recovery and resilience plan}

The recovery and resilience plan of the Slovak Republic is divided into five basic areas: better education for everyone ( 850 million $€$ ), competitive and innovative Slovakia (700 million $€$ ), green Slovakia (1,900 million $€$ ) healthy life for everyone (1,450 million $€$ ) Effective state and digitisation (945 million $€$ ) (POOSR, 2020).

\section{Priorities of Slovakia for the programming period 2021 - 2027 in the field of Ecological Slovakia for future generations}

The needs for high-priority investments are designed to support energy efficiency and renewable energy measures, and the creation of intelligent energy systems. 8117 million euro from the European Regional Development Fund and 1613 million euro from the Cohesion Fund should be allocated to this area. This proposal will be approved by the Government of the Slovak Republic in April 2021. Subsequently, this document of the Partnership Agreement will be submitted to the European Commission. The approval process will take place in the second half of 2021 (NKE, 2020).

2.1.1 Support for measures to improve energy efficiency and reduce greenhouse gas emissions

To increase energy efficiency, interventions will further focus on improving the energy performance of buildings. The aim is to create a highly energy-efficient and decarbonised building stock that will have the effect of reducing costs, improving the competitiveness of businesses and tackling energy poverty. The EU Structural Funds have so far been a key resource in this area, with significant results in reducing energy consumption in public buildings, households and industry. (SRprePS, 2018).

2.1.2 Support for energy from renewable sources

The EU's climate and energy goals will be ambitious in the 2021-2027 programming period and will require targeted and effective support for RES as a key segment in tackling climate change migration. At the same time, however, their development will need to be guided by the principles of sustainability (especially in the case of biomass). Annually, it is necessary to increase the production of heat/cold from RES by at least $125 \mathrm{GWh}$, which in 2025 will reach the value of the share of heat from RES by approximately $41.5 \%$ (compared to consumption in 2016). The Slovak Republic has experience with the implementation of projects of modernisation and reconstruction of energy distribution financed from ESIF 2014-2020, including the implementation of projects of local use of RES, and these represent a strong potential in the new programming period (SRprePS, 2018).

By the end of 2017, there were 17,783 biogas plants in operation throughoutin Europe (Fig. 4), following a decade of steady growth. This growth did not stop even when some EU countries faced various political upheavals. Within the past five years, 3,122 new plants have been installed to give an increase of $18 \%$. In the year 2017 alone, an increase of $2 \%$ in the total number of biogas plants was achieved (EBA, 2018).

Between 2016 and 2017, there was no increase in the number of facilities in several European countries, such as AT, EE, HU, IC, IE, NO and RO. No more than 10 additional biogas plants were registered in BE-Wallonia, 
$\mathrm{CH}, \mathrm{CZ}, \mathrm{DK}, \mathrm{FI}, \mathrm{EL}, \mathrm{PO}, \mathrm{PT}, \mathrm{RS}$ and SK. The list of countries with the greatest increase in 2017 were Germany (+122 plants), followed by Italy (+100 plants), France (+74 plants), the UK (+55 plants) and Spain (+43 plants) (EBA, 2018).

Different studies released in 2019 support the existence of a considerable untapped potential for biogas and biomethane, essential for the transition to carbon neutrality. This solid scientific evidence shows positive trends in production figures, highlights opportunities for usage as transport fuel and confirms positive impact in terms of job creation, infrastructure savings or reduction of emissions (EBA, 2020)

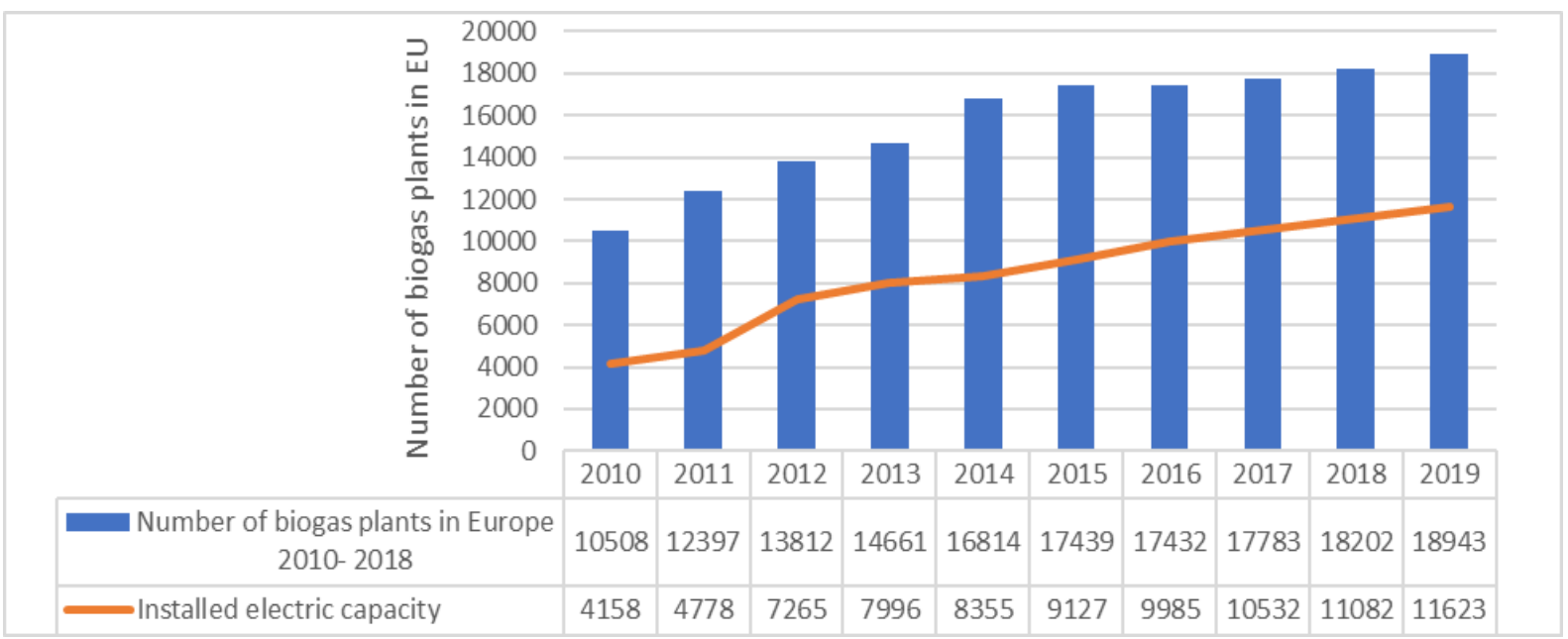

Fig. 4 Number of biogas plants and Installed electric capacity in Europe 2010-2019

Source: EBA, 2020

The most recent data gathered by the EBA show that 2018 saw a total of 18,202 biogas installations (Fig. 4), a Europe-wide installed electric capacity (IEC) of 11,082 MW, and 63,511 GWh of biogas produced. Biomethane, the upgraded form of biogas, has been increasingly in the spotlight, and 2018 was no exception, as the European biomethane sector continued its dynamic growth, to reach a total of 660 plants producing 2.28 bcm of biomethane (EBA, 2019).

The EBA is regularly monitoring the state of play of biogas and biomethane. According to the data collected by the EBA for the Statistical Report 2020, biogas production is starting to stabilise, whereas biomethane production is escalating. By the end of 2019, Europe had 18,943 biogas plants with a combined biogas production of $15.8 \mathrm{bcm}$ (EBA, 2020).

If the sector keeps up with this pace, there is a consensus that by 2030, the biogas and biomethane sectors combined can almost double their production, and by 2050, production can more than quadruple. The estimated potential ranges between $34-42 \mathrm{bcm}$ (equivalent to $370-467 \mathrm{TWh}$ ) by 2030. By 2050, the potential is estimated at $95 \mathrm{bcm}(1,008-1,020 \mathrm{TWh})$. The EBA strategy for the coming years estimates that the biomethane sector alone will be able to reach $34 \mathrm{bcm}$ of sustainable biomethane by 2030 (EBA, 2020).

\section{Operating procedure of biogas plants}

Only renewable raw materials (for example, maise silage, cereal) and slurry will be used for the production of energetically usable biogas by means of the anaerobic conversion of biomass. In particular, renewable biofuels within the meaning of Regulation (EC) No 1774/2002 shall be used in the biogas plant. Renewable raw materials such as corn silage, grain, etc., are dosed directly into the fermenters as a solid load. Slurry enters the fermenter from a covered collecting tank.

The collection tank, fermenter, additional fermenter and storage of fermentation products are made as round tanks made of reinforced concrete. All are covered with a special conical gas-tight foil. Thus, the discharged biogas can be collected directly above the surface of the liquid mixture of reservoirs and stored before proceeding to the subsequent processing process. The second conical foil, buoyed by the air supplied by the radial blower, is kept with an internal overpressure of about $1.5 \mathrm{mbar}(1.5 \mathrm{~cm}$ of water column pressure $)$ in the form of a foil cover against the influence of the external environment. The underpressure/overpressure protection device serves to maintain constant pressure under and between the foils.

Fermenters are operated in the range of mesophilic fermentation at a temperature of about 40 degrees Celsius. In principle, a thermophilic operating mode is also possible. Tempering of the fermentation substrate is performed using hot water supplied by an external heating source. After a corresponding delay in the fermenters and after the fermentation substrate has been gassed, this filling is closed - either connected to the inserted pump (in the case of tanks with a height of $8 \mathrm{~m}$ ) or by means of a transfer line (in the case of tanks with a height of up to $6 \mathrm{~m}$ ) variant - 
fed into a gas-tight tank (additional fermenter). From it, the transfer of the filling to the next/other warehouse/warehouses of fermentation products (for final storage) is performed according to the offer - again by means of a connection with the inserted pump/overflow pipe. Fermentation products are stored here until exported to agricultural areas.

By fermentation of renewable raw materials (for example, corn, grass, grain, etc.), energy-rich biogas is obtained. The fermentation product remaining after anaerobic fermentation in the biogas plant will be further used in agricultural production as a fertiliser and thus return to the organic farming cycle of the farms that supply the plant to the plant.

The economic purpose of a biogas plant is to obtain biogas and sell it on the market. Useful, targeted side effects of anaerobic biomass processing are:

- $\quad$ improving the quality of the substrate as a fertiliser by converting organic substances into a mineral form and thus enabling the immediate use of the substrate that has undergone the fermentation process (fermentation residues, digestate),

- reduction of the greenhouse effect due to the replacement of fossil fuels and fuels by biogas,

- inactivation of germination and spread of weed seeds,

- the use of the substrate after fermentation as a high-quality substitute for fertilisers in the process of supplementing nutrients on useful agricultural areas and thus at the same time achieving the return of organic matter to nature.

Anaerobic processing of biomass in this way serves to produce energy-rich biogas, to improve the quality of fertilisers and also to obtain a high-quality substitute fertiliser for plants, thus helping to replenish nutrients on agricultural land.

\section{Process management}

Anaerobic biogas production takes place due to the biodegradation of organic substances by methanogenic bacteria, with the exclusion of oxygen and light, within a certain temperature window. Fermentation temperature and residence time in the fermenter are the most important parameters of the anaerobic process. The biogas plant, defined by this assignment, will be operated in mesophilic fermentation mode at about $40{ }^{\circ} \mathrm{C}$. In principle, a thermophilic operating mode is also possible. With sufficient residence time of the biomass in the fermentation process, hygienization and stabilisation of the substrate are achieved.

The obtained biogas, a product of metabolism performed by methanogenic bacteria, can be described in terms of its physical properties as follows:

Tab. 1 physical properties of the obtained biogas

\begin{tabular}{|l|l|l|l|l|}
\hline Physical characteristics & $\mathbf{C H}_{\mathbf{4}}$ & $\mathbf{C O}_{\mathbf{2}}$ & $\mathbf{H} \mathbf{S}$ & $\begin{array}{l}\text { biogas } \\
(\mathbf{6 5} \% \mathbf{C H}\end{array}$ \\
\hline Volume share in biogas $(\%):$ & $55-75$ & $24-44$ & $0,1-0,7$ & 100 \\
\hline Calorific value $\left(\mathrm{kWh} / \mathrm{m}^{3}\right):$ & 10 & - & 6,3 & 6,6 \\
\hline Thermal value $\left(\mathrm{kWh} / \mathrm{m}^{3}\right):$ & 11,1 & - & - & 7,2 \\
\hline Explosion band $($ volume \%): & $5-15$ & - & $4-45$ & $6-12$ \\
\hline Ignition temperature $\left({ }^{\circ} \mathrm{C}\right):$ & 650 & - & 270 & $700-750$ \\
\hline Critical temperature $\left({ }^{\circ} \mathrm{C}\right):$ & $-82,5$ & 31 & 100 & $-82,5$ \\
\hline Density $\left(\mathrm{kg} / \mathrm{m}^{3}\right):$ & 0,72 & 1,98 & 1,54 & 1,2 \\
\hline
\end{tabular}

\section{Technical data of the biogas plant project}

The biogas plant, including the relevant ancillary components, shall include, after compliance with the required measures, the following main technical operational and design data:

Loading system - (BE 010)

The loading system is used to supply biomass processing equipment, such as corn silage, in a solid consistency that cannot be pumped. The loading system includes a substrate hopper, a sliding feeder at the bottom of the hopper, electrically driven screw feeders (conveyor screw, dosing screw, etc.) and a weighing system. The renewable raw materials are poured from the substrate hopper to the screw conveyor at the bottom by means of a sliding feeder and are fed to the fermenter by a dosing screw.

Because the dosing of nutrients for microorganisms in a biogas plant must take place in order to maintain a stable and uninterrupted production several times a day at intervals that are specifically specified, the dosing is automated.

Fermentor with integrated low-pressure gas tank - (BE 030 and BE 040)

(Constructionally identical) fermenters with a low-pressure gas tank above the level of the substrate charge are set up as reinforced concrete circular tanks in accordance with generally accepted technical rules expressed in 
DIN 11622 "Fermentation silos and slurry tanks" as well as "Water management requirements for slurry storage and bottling equipment. slurry and silage juices ".

Renewable raw materials (for example, corn silage) are dosed using a loading system (BE 010). The fermenter (s) (BE 030 and BE 040) is/are connected to the auxiliary fermenter (BE 050) via a pump circuit/overflow line. When the fermentation charge is metered into the fermenter (s), the same amount of fermentation substrate is transferred to the subsequent additional fermenter by means of a closed pump circuit/overflow line - according to the offer. If the additional fermenter is full, then the liquid fermentation substrate is moved to the fermentation residue store (s) (BE 060, BE 070 and BE 080) according to the same principle.

All containers are closed with conical foils (material: top foil made of PVC fabric, lower foil made of highly elastic PE) and a special pressure bar, which fastens the foil to the container in a gas-tight manner. Between the two foils, the externally located radial blower maintains a maximum air overpressure of $1.5 \mathrm{mbar}(1.5 \mathrm{~cm}$ water column); space is secured by a pressure relief flap. The raw gas is biologically desulphurised with controlled dosing of air into the gas tank and, after drying by the method of water vapour condensation, introduced into the gas treatment plant / CHP. The volume quantity of the supply air for the desulphurisation of the raw gas is, depending on the appropriate dosage, a maximum of $6 \%$, based on the volume quantity of the raw gas.

Additional fermenter with integrated low-pressure gas tank - (BE 050)

The additional fermenter with a low-pressure gas tank above the level of the substrate charge is set up as a reinforced concrete circular tank in accordance with generally accepted technical rules expressed in DIN 11622 "Fermentation silos and slurry tanks" and also according to "Water management requirements for slurry, slurry and silage storage state". Like the fermenter (s) (BE 030 and BE 040), it is equipped with wall heating, insulation and roofing with air-borne foils together with an integrated low-pressure gas tank. For the purpose of mixing the charge, the additional fermenter is equipped with submersible motor stirrers.

\section{Fermentation residue warehouse - (BE 060, BE 070 and BE 080)}

From the additional fermenter of the biogas plant, the fermented substrate (digestate) is transferred to the fermentation residue store (s) by means of a pumping circuit/overflow line. The storage (s) of fermentation residues is/are made as reinforced concrete round tanks in accordance with generally accepted technical rules, according to the principles for "Fermentation silos and slurry tanks" and also according to "Water management requirements for equipment for storage and bottling of slurry, slurry and silage juices ". It is/are equipped with an air-borne foil roofing together with an integrated low-pressure gas tank. The establishment and operation of low-pressure gas storage comply with the safety regulations for biogas plants. In order to prevent the formation of floating cakes, to ensure the homogenisation of the substrate and its mixing, the fermenter (s) is/are equipped with adjustable submersible motor stirrers.

\section{$\underline{\text { Internal combustion engine unit KGJ - (BE 090) }}$}

KGJ is located in a concrete noise protection cover; this container is equipped with all the necessary technical accessories. Exhaust air is removed from the engine room by means of ventilation fans automatically controlled from the temperature and discharged into the open space. No drains are led to the floor of the engine operating space in an organised manner. The floor and wall sections are designed to be impermeable to operating media. These operating sections are regularly inspected daily on a daily basis for leaks of operating media.

The flue gases from the internal combustion engine are discharged into the surrounding atmosphere through the flue gas chimney after heat dissipation. The flue is dimensioned according to what the engine requires in terms of flue gas flow rate, temperature and flow, and according to the concentrations of pollutants and their output volume.

\section{Discussion}

Innovation policy is part of strategic frameworks in all spheres of society's development, and in the last decade, its horizontal and vertical interconnection with several sectors has been clear (Soltes \& Gavurova, 2014). Also, at the macro level, the goals of innovative development of countries are part of the evaluation of macroeconomic economic cycles, while innovation development is considered as an accelerator of the economic development of countries (Bilan et al., 2017). The use of renewable energy sources is an important part of largescale, complex innovation processes, which also affect the development of competitiveness not only of countries but also of regions within them (Gavurova et al., 2017).

Slovakia has not met its renewable energy targets for a long time. The government has therefore included the development of renewable energy among the priorities in the national reform proposal. It wants to subsidise not only new renewables from this instrument but also to review and extend support schemes for existing resources. This also applies to biogas plants, which lost their guaranteed purchase prices at the end of 2020, with which the state subsidises electricity from renewable sources. The draft reform plan implies that the regulatory policy will open the door to innovation with the possibility of recovering biodegradable waste in line with the Environmental Strategy until 2030. Under this strategy, only biogas plants that collect sorted biodegradable waste should receive public support. According to the Environmental Strategy, the by-product, the so-called digestate, should be used 
as a fertiliser by 2030. The treatment of biowaste in biogas with the subsequent use of biomethane and digestate is in accordance with the principles of a circular economy. This is a fundamental pillar of the European Green Agreement, which aims to steer the Member States towards carbon neutrality. In Slovakia, it is necessary to process biowaste from households in the amount of 100 thousand tons. Regarding the use of energy from bio-waste, it is possible to decide whether biomethane will be pushed into the grid or electricity will be produced from it.

Approximately $74 \mathrm{~m} 3$ of biomethane can be produced from one tonne of biowaste, for example, from food residues from restaurants, in a waste biogas plant. In Slovakia, however, biogas is currently predominant, which recovers mainly waste from agricultural production. However, new generations of biog as plants are able to process municipal waste, food waste or sewage sludge. Slovakia hardly uses this energy source, as most kitchen waste ends up in landfills or incinerators. It creates methane, which acts as a powerful greenhouse gas. Because biomethane is similar to natural gas, it has a very wide range of uses.

There are currently 113 biogas plants in Slovakia, and they are not currently easily operated. They are running operating costs and looking for resources to invest in the future to produce biomethane and alternative fuels such as bioCNG and bioLNG. Biogas plants are experiencing a difficult situation not only due to the lack of funds but also due to the weaker silage harvest. Poor cooperation of the owners caused up to $40 \%$ of projects are in bankruptcy. The most common reasons are a large credit burden, reduced supply of inputs and lower production, which causes a lack of funds to pay off loans. In western Slovakia, up to $60 \%$ of biogas plants are in bankruptcy. This situation also occurred due to poorly set legislation regarding URSO, but mainly due to the unclear and inaccurate specification of Act 309/2018 of the Collection of Laws. The result of these events is a lack of interest in bank support, which has resulted in a biogas plant with an investment cost of $€ 3.5$ million that can now be bought at the bank worth $€ 150,000$. There are ten of the 113 such biogas plants in Slovakia.

As many as twenty biogas plants have switched from silage production to biodegradable waste. The technology is modified, but state support is not enough. Purchasers and the unclear waste policy of the state mean that biogas plants do not have as much income as they should. Insufficient control of the veterinarians, hygiene and the environment of waste producers means that most is produced in the fields without recovery, which degrades the soil and can result in the multiplication of diseases and other pests. Today, there are four biogas plants in Slovakia with sanitation, which can also process animal waste.

\section{Conclusion}

Slovakia is one of the countries with negligible RES potential. Potential energy from biomass lies mainly in heat production. It is only now a quarter of the used biomass potential. Higher utilisation rates are possible with the active application of existing technologies that are changed by legislative, administrative and environmental criteria. In the EU, there are many mechanisms to support RES depending on the geographical location, natural elements of the landscape and scope of support measures. The support system of each Member State is determined individually, and different forms of support may vary in size and character. The problem is determined by the optimal level of support for RES, which leads to a conflict of views between private investors and consumers. There are several schemes to promote energy from renewable sources and the construction of new renewable energy systems. Regions play an important role in their use.

Sustainable development have to meet the current needs of the population without restricting the ability of future generations to meet their own needs. Therefore, it is necessary to move to more modern and environmentally friendly technologies that will help us change procedures and habits both in terms of production and consumption.

The main quantified energy and climate targets for 2030 are, across the Union, achieve a reduction in greenhouse gas emissions of at least $40 \%$ compared to 1990. A binding target at EU level is to achieve a share of renewable energy sources in gross final consumption of energy of at least $32 \%$, with the share of RES in each EU Member State in the field of transport must be at least 14\%. At least 32.5\% should be the national contribution to energy efficiency and at least $15 \%$ should be interconnected electrical systems.

Slovakia has set its main qualified targets for 2030, which are to reduce greenhouse gas emissions for nonemissions sectors by $20 \%$. The use of RES for final consumption is set at $2030 \%$ by 2030 , meeting the required target of 14\% RES in transport. In 2019, the use of RES for final consumption was $16.90 \%$, which means that the Slovak Republic could achieve the set target earlier than in 2030. In the sector of electricity production from RES, the NECP proposal from 2018 set an indicative target of $25 \%$ for 2030; for the $19.2 \%$ target, it corresponds to $27.3 \%$, which is on the verge of technical possibilities of the Slovak electricity system. One of the alternatives to increase the total share of RES in 2030 from $19.2 \%$ to $20 \%$ is in the area of heat production. However, this would mean higher use of biomass, including biogas production and biomethane (originating mainly from wastes from plant and animal production, from biological degradable part of municipal waste, biodegradable kitchen and restaurant waste and waste from wastewater treatment plants), heat pumps, solar panels and geothermal energy in $\mathrm{DH}$. The higher use of RES in the heat sector is counteracted by the high level of surface area gasification, in which more than $90 \%$ of the population has access to natural gas. Transition to biomass from natural gas in family houses is therefore problematic in terms of air quality, which would could jeopardise compliance with EU 
legislation. One of the solutions is the implementation of biomethane and hydrogen in the existing gas infrastructure.

\section{References}

Bauer, A., Leonhartsberger, C., Bosch, P., Amon, B., Friedl, A., Amon, T. (2010). Analysis of methane yields from energy crops and agricultural by-products and estimation of energy potential from sustainable crop rotation systems in EU-27. Clean Technol Environ Policy (12), 153-161.

Bilan, Y., Gavurova, B., Stanislaw, G., Tkacova, A. (2017). The Composite Coincident Indicator (CCI) for Business Cycles. Acta Polytechnica Hungarica, 14(7), 71-90.

Biomasa- plány do roku 2030. (2019) [online] Available at: https://ec.europa.eu/energy/sites/default/files/documents/biosustain_annexes_final.pdf

Ciucci, M., (2020). Informačné listy o Európskej únii- Energia z obnovitel'ných zdrojov. [online] Available at: https://www.europarl.europa.eu/factsheets/sk/sheet/70/renewable-energy

Detersová, K., (2020). Podiel energie z obnovitel’ných zdrojov na Slovensku vzrástol o pol percentuálneho bodu. [online] Available at: https://euractiv.sk/section/energetika/news/podiel-energie-z-obnovitelnych-zdrojovna-slovensku-vzrastol-o-pol-percentualneho-bodu/

Ellabban, O., Abu-Rub, H., Blaabjerg, F. (2014). Renewable energy resources: Current status, future prospects and their enabling technology. Renewable \& sustainable energy reviews. (39), 748- 764.

Eurostat- Energy. (2020). [online] Available at: https://ec.europa.eu/eurostat/databrowser/view/t2020_31/settings_2/table?lang=en

Energia z obnovitel'ných zdrojov: významný aktér na euróspkom trhu s energiou (COM(2012(0271). (2019). [online] Available at: https:/eur-lex.europa.eu/legalcontent/SK/TXT/PDF/?uri=CELEX:52012DC0271\&from=SK

Eurostat. (2019). [online] Available at: https://ec.europa.eu/eurostat/cache/infographs/energy/bloc-2c.html

European Biogas Association. (2019). EBA Biomethane and Biogas Repost 2019. [online] Available at: https://www.europeanbiogas.eu/wp-content/uploads/2020/01/EBA-AR-2019-digital-version.pdf

European Biogas Association. (2018). EBA Biomethane and Biogas Repost 2018. [online] Available at: https://www.europeanbiogas.eu/wp-content/uploads/2019/05/EBA_Statistical-Report2018_AbrigedPublic_web.pdf

European Biogas Association. (2020). EBA Biomethane and Biogas Repost 2020. [online] Available at: https://www.europeanbiogas.eu/wp-content/uploads/2021/01/Annual-Report-2020-new.pdf

Fan, S., Freedman, B., Gao, J. (2007). Potential environmental benefits from increased use of bioenergy in China. Environ Manage (40), 504-515.

Gavurova, B., Soltes, M., Kovac, V. (2017). Application of Cluster Analysis in Process of Competitiveness Modelling of Slovak Republic Regions. Tranformations in Business \& Economics, 16(3), 129-147.

Integrovaný národný energetický a klimatický plán na roky 2021 - 2030. (2019). [online] Available at: https://ec.europa.eu/energy/sites/default/files/documents/sk_final_necp_main_sk.pdf

Jaber, JO., Badran, OO., Abu-Shikhah, N. (2004). Sustainable energy and environmental impact: role of renewables as clean and secure source of energy for the 21 st century in Jordan. Clean Technol Environ Policy (6), 174-186.

Legislatívne nástroje SR, Ministerstvo životného prostredia SR. (2020). [online] Available at: https://www.minzp.sk/klima/obnovitelne-zdroje-energie/podpora-oze/legislativne-nastroje-sr/

Kleinert, T., Schmidt, M. (2019). Global optimisation of multilevel electricity market models including network design and graph partitioning. Discrete Optimiza- tion, (33) , 43-69.

Ministerstvo financií SR. Plán obnovy Slovenska. (2020). [online] Available at: https://www.mfsr.sk/sk/media/tlacove-spravy/predstavujeme-dalsie-detaily-planu-obnovy.html

Národná konzultácia $\mathrm{k}$ Eurofondom 2021- 2027. (2020). [online] Available at: https://www.mirri.gov.sk/sekcie/cko/narodne-konzultacie-k-eurofondom-2021-2027/index.html

National energy and climate plans. (2019). [online] Available at: https://ec.europa.eu/energy/topics/energystrategy/national-energy-climate-plans_en?redir=1

Oznámenie komisie európskemu parlamentu, rade, európskemu hospodárskemu a sociálnemu výboru a výboru regiónov. Plán postupu v energetike do roku 2050. (2020). [online] Available at: https://eurlex.europa.eu/LexUriServ/LexUriServ.do?uri=COM:2011:0885:FIN:SK:PDF

Plán obnovy a odolnosti SR. (2020). [online] Available at: file:///C:/Users/Antonio/Downloads/Plan_obnovy_Slovenska.pdf

Pozo, D., Sauma, E.E., Contreras, J. (2013). A three-level static MILP model for generation and transmission expansion planning. IEEE Transactions on Power Systems , 28(1), 202-210. 
Sauma, E.E., Oren, S.S. (2009). Do generation firms in restructured electricity markets have incentives to support social-welfare-improving transmission investments. Energy Economics, 31(5), 676-689.

Smernica 2009/28/ ES- plany do 2020. (2017). [online] Available at: https://eur-lex.europa.eu/legalcontent/SK/TXT/PDF/?uri=CELEX:32009L0028\&from=EN

Soltes, V., Gavurova, B. (2014). Innovation policy as the main accelerator of increasing the competitiveness of small and medium-sized enterprises in Slovakia. Emerging Markets Queries in Finance and Business (EMQ, 2013). Ed. Stefan, D.; Comes, C.A.; Munteanu, A.; Nistor, P.; Stefan, A.B. Procedia Economics and Finance, 15, 1478-1485. DOI: 10.1016/S2212-5671(14)00614-5

Svensson, L.M., Christensson, C.K., Bjornsson, C.L. (2006). Biogas production from crop residues on a farmscale level in Sweden: scale, choice of substrate and utilisation rate most important parameters for financial feasibility. Bioprocess Biosyst Eng (29), 137-142.

Stürmer, B., Schmid, E., Eder, MW. (2011). Impacts of biogas plant performance factors on total substrate costs. Biomass and Bioenergy (35), 1552-1560.

Uddin, S., Taplin, R., Yu, X. (2010). Towards a sustainable energy future-exploring current barriers and potential solutions in Thailand. Environ Dev Sustain (12), 63-87.

Východiskový návrh priorít SR pre politiku súdržnosti na programové obdobie 2021 - 2027. (2020). [online] Available at: https://www.eurofondy.gov.sk/wpcontent/uploads/2019/11/V\%C3\%BDchodiskov\%C3\%BD-n\%C3\%A1vrh-prior\%C3\%ADt-SR-pre-PS2021-2027-final-upraven\%C3\%BD-po-RV.pdf 